\title{
Surfaces
}

\section{Shakespeare and the Formation of the Modern Economy}

\section{Richard Waswo}

Volume 6, 1996

LES ÉCONOMIES DISCURSIVES DU SAVOIR ET DE LA CULTURE DANS LE SILLAGE DE L'OEUVRE DE BILL READINGS

THE DISCURSIVE ECONOMIES OF KNOWLEDGE AND CULTURE, WITH CONSTANT REFERENCE TO THE WORK OF BILL READINGS

URI : https://id.erudit.org/iderudit/1064862ar

DOI : https://doi.org/10.7202/1064862ar

Aller au sommaire du numéro

Éditeur(s)

Les Presses de l’Université de Montréal

ISSN

1188-2492 (imprimé)

1200-5320 (numérique)

Découvrir la revue

Citer cet article

Waswo, R. (1996). Shakespeare and the Formation of the Modern Economy. Surfaces, 6. https://doi.org/10.7202/1064862ar
Résumé de l'article

En décrivant la monnaie et les mots comme une système homologue qui constitue, transmet et change les valeurs, cet essai explore la période de formation de l'économie moderne, au moment où les écrivains du XVIe siècle luttaient pour la conceptualiser, et où Shakespeare mettait en scène ses principes de base.
Copyright (C) Richard Waswo, 1996

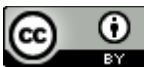

Ce document est protégé par la loi sur le droit d'auteur. L'utilisation des services d'Érudit (y compris la reproduction) est assujettie à sa politique d'utilisation que vous pouvez consulter en ligne.

https://apropos.erudit.org/fr/usagers/politique-dutilisation/ 


\title{
Shakespeare and the Formation of the Modern Economy
}

Richard Waswo

Département d'Anglais

Faculté des lettres

Université de Genève

waswo@uni2a.unige.ch

Surfaces Vol. VI. 217 (v.1.0A - 21/12/1996) - ISSN:

1188-2492

Copyright for texts published in Surfaces remains the property of authors. However, any further publication should be accompanied by an acknowledgement of Surfaces as the place of initial publication.

\begin{abstract}
Describing money and words as homologous systems that function to constitute, transmit, and alter values permits this essay to explore the formative period of the modern economy, when sixteenth-century writers were struggling to conceptualize it, and

Shakespeare was dramatizing its basic principles.
\end{abstract}

\section{RÉSUMÉ}

En décrivant la monnaie et les mots comme une système homologue qui constitue, transmet et change les valeurs, cet essai explore la période de formation de l'économie moderne, au moment où les écrivains du XVIe siècle luttaient pour la conceptualiser, et où Shakespeare mettait en scène ses principes de base. 
In a postscript to his diagnosis of postmodernity, JeanFrançois Lyotard describes capitalism as "infinite will," and finds it at present to be invading language itself, transforming it into a "productive commodity" by means of computerized treatment and exchanges of "information." On this basis, he offers a warning that updates the ancient analogy that I wish here to explorethat between words and money:

The effects of the penetration of capitalism into language are only beginning. Under the guise of an extension of markets and a new industrial strategy, the coming century is that of the investment of the desire for infinity, according to the criterion of optimum performance, in matters of language.

Language is the whole social bond (money is only an aspect of language, the accountable aspect, payment and credit, at any rate a play on differences of place or time). This investment of the desire for the infinite in language is thus going to destabilize the living creations of social life itself. (1993: 27).

Assuming the Saussurean description of semantics as a "play on differences," Lyotard boldly subsumes the operations of currency and credit under those of language itself, as Saussure identified it in the largest sense as a "social fact." Lyotard's parenthesis thus englobes what had traditionally been perceived as a mere analogy-which I shall be describing by the somewhat stronger term of "homology." Not only this homology, but also the effect that Lyotard attributes to computerization, has a rather longer history. Capitalism, according to Lyotard, consists in commodification, or the determination of values by the "indifferent" mechanisms of exchange, the "commensurability" of all things (Readings 1991: 102). If so, this process, and reflection about it, goes back as far as Aristotle, who certainly found it to "destabilize" properly "social" life. Even more destabilization was observed during the period that concerns me here, the onset of modernity in the late Renaissance. It was in the fifteenth century that the word "commodity" (in English and in French) began to shift from designating the useful qualities of an object (what was "commodious" about it) to objects produced exclusively for sale. 
By 'words' I understand any and all uses of language; by 'money' I include not only cash but all negotiable, exchangable, enforceable, instruments of credit. I propose to present some twentieth-century accounts of these operations, and then to describe the historical moment, in the sixteenth century, when they were beginning to be both conceptualized and, in two plays of Shakespeare, dramatized.

As sociopolitical institutions, words and money have been seen as homologous since Quintilian, who wrote: "Custom indeed is the indisputable mistress of speaking, and language is to be employed just like currency, as having the public stamp."[ $\underline{\mathbf{1}}$ ] The comparison echoed down the centuries to the Enlightenment, when the Marquis de Mirabeau expressed it thus: "The two greatest inventions of the human mind are writing and money-the common language of intelligence and the common language of self-interest" (Clodd 1938). The most seminal development of the homology in this century is that of Saussure himself, whose discussion of linguistic value (Course in General Linguistics 2.4.2) makes explicit the identical way that words and coins work: by being exchanged for something dissimilar (ideas or goods), and by being compared to something similar (other words or currencies). For Saussure, these processes in fact establish values, determine them. He arrives at the somewhat revolutionary notion that both linguistic and monetary values-the meaning of words and the worth of coins--are not intrinsic but differential. That is, they depend not on any fixed characteristic of the objects (the referent of the word or the coin's content of precious metal), but on the fluid process itself of exchanging and comparing them, on their relations with what is both like and unlike them. Values are thus established in and by usage, just as Quintilian declared. Custom-what Saussure called the "social fact"-rules, gives the currency to both words and coins.

Just this argument about money alone had been more extensively made in 1907 by Georg Simmel, who approaches it from the general angle of valuation. Value, says Simmel, is a social and psychological process that inheres not in objects but is rather "like light and shade" cast on them from a different source: people (1978: 60). Value is a claim of significance or recognition, a shared sentiment that is thus neither "subjective" nor "objective" (68). Because it is constituted in the process of exchange itself, value is "supra-individual, yet without becoming an objective quality ... of the things themselves" (78).[ 2 ] Demand and scarcity do not 
constitute value, but are merely its relative conditions (72). Objects do not "have" values in order to be exchanged; rather, their ability to be exchanged creates their value, which, consequently, is always contingent and never absolute or fixed (86-90). Simmel offers analogies throughout this discussion of monetary values with erotic and religious ones, insisting that their constitution and operation are the same. He summarizes his findings in a remark that states the principle of differential contingency (what he calls "interaction"), and that Saussure might well have made about words: "The philosophical significance of money is that it represents within the practical world the most certain image and the clearest embodiment of the formula of all being, according to which things receive their meaning through each other, and have their being determined by their mutual relations" (128-29). Simmel also presents a careful and extended demonstration that the substance of money is consequently irrelevant, that it logically need have no putatively "intrinsic" value at all. Gold and silver he finds merely convenient, whereas to be "conceptually correct" would require a "pure token money," a pure symbol or function, wholly detached from any precious substance. Simmel does not foresee, in 1907, any such supersession of precious metals, but thinks that "the actual [historical] development of money suggests that this will be the final outcome" (165). As indeed, we'll see in a moment, it was.

Before looking at this history, however, it would be well to dispose of the commonest objection to the homology itself, the denial that words and money can be cogently compared. Despite the ancient pedigree of the comparison, one obvious difference between words and money has sometimes been invoked to invalidate it. This is simply the fact that one can produce words inexhaustibly, but not money: when one spends it, it's gone. I and anyone else can use words without any external limit; but our use of money is all too limited by the amount we have at any given moment. This difference, however, between the quantitative expenditure of words and money by an individual, in no way invalidates the homology, which operates at another level. It describes not individual uses of either words or money, but rather the system in which all such uses take place, which enables the individual to communicate or spend anything at all. The many and necessary differences among individuals' access to the system-all possible vagaries and varieties of linguistic and monetary acquisition-are not in question here. For the homology is systemic; it compares the operation of two basic social institutions-language and money-as systems 
of exchange, at once symbolic and material. And it suggests that both systems work in the same way.

If so, then we might also expect them to be thought about in the same way, that is, to find their conceptualization, at any given period, to be analogous to their operation. And we should further expect that both operation and conceptualization would show analogous alterations over long periods of time. This expectation might take its inspiration from Michel Foucault's analysis (1970) of how the discursive practices concerning words and money change in identical ways at the turn of the nineteenth century. Something similar, I believe, could be demonstrated in the Renaissance-not something so neat as a clear-cut change, but rather something like a common problematic, the discovery of identical dilemmas in discourse about words on the one hand and money on the other.[ $\underline{\mathbf{3}}$ ]

The contemporary realization of Simmel's logical analysis of money will suggest something of the force and persistence of the homology. For it so happened that at just the time when money was officially decreed to be a pure token or function, occurred the explosion of theories of textual indeterminacy. The American government, under President Nixon, decided in 1971 to cut the dollar loose from any determinate relation to precious metals and let it "float," its value becoming wholly dependent on its ever-fluctuating relation to other currencies. Something very like what Foucault would call an epistemic change seemed to be at work here. For at just this period, in the late sixties and early seventies, post-structuralist theorists like Jacques Derrida, Roland Barthes, and Julia Kristeva, were producing a conception of textual meaning as wholly indeterminate, unconstrained by any traditional notion of reference, intention, or context; freely floating to be freely played with amid the infinite possibilities of recombining everfluid signifiers. And at this moment, President Nixon took the unprecedented step in modern history of declaring the dollar free of any obligation to represent or refer to any presumed external repository of intrinsic worth. The dollar, of course, could no longer, since the Bretton Woods agreement of 1946 (which established the rules of the first world's post-war economy), actually be exchanged at a federal bank for a quantity of silver or gold; but it was "pegged" to such a quantity, was stipulated to be worth so much of these substances, in order that exchange rates between currencies would remain fixed. But in 1971 the dollar was unpegged, the rates unfixed, and the logic of Quintilian's and 
Saussure's criterion of social use was enacted with respect to money. It was, and remains, as Simmel saw, the logic of long practice: coins in this century had steadily been diminishing in their content of precious metal, and function today without containing any at all. Currency is current-that is, has its value-by consensus and by mutual relation; it need not and does not either have any material, intrinsic value or represent any. It floats, and nowadays circulates globally in invisible and immaterial ways, a pure function, winged by the plastic cards and electronic impulses that operate the world's system of credit.

Today's monetary system thus realizes the worst anxieties of late medieval and early modern economists, just as, indeed, the doctrine of textual indeterminacy would have horrified almost any Renaissance commentator on the Bible. But perhaps the best evidence that discursive practices about words and money are linked and homologous is that when they change, they always encounter the same kinds of resistance. I need not rehearse the chorus of contemporary protest against the doctrine of textual indeterminacy in the name of all the traditional constraints that doctrine discarded. As for our presently floating currencies, I need only cite an article that recently appeared in theWall Street Journal, urging a return to the convertible gold standard for the dollar, as this existed before the agreement of Bretton Woods (Lehrman 1990).[ $\underline{4}$ ]

Such resistance, such stubborn attachment to the notion of intrinsic or objective or inherent value was precisely what characterized discourse about money when it first tried, in the sixteenth century under the pressure of the galloping inflation set off in Europe by the influx of silver from the new world, to conceptualize the modern economy. The attitude was typified by Marco Polo's earlier incredulity that at the court of the Great Khan, something entirely worthless could function as money. He is amazed that throughout the realm, even those objects thought to possess supreme value in the Westjewels, gold, and silver-are themselves purchased by paper. The paper, made from mulberry bark, was black and stamped with some heraldic device of the Khan. Polo marvels that such intrinsically worthless stuff, so much lighter and insubstantial than all the things it can buy, is nonetheless gratefully accepted by all the merchants in the kingdom. The Khan himself keeps a great store of gold and silver (hence his fabulous wealth), and prints, says Polo, as much of the paper "as he pleases." But since everyone accepts it, Polo concludes, "the value is 
the same to them as if it were of gold or of silver" (Polo 1938: 238-40).

The value certainly isn't the same to him, however, for he shares the ancient fixation on value as something intrinsic to the object itself. The fixation descends from Aristotle, from whom the Renaissance inherited its standard view of money, as of much else. In his discussion of the basic unit of politics, the household (oikos), Aristotle outlined the nature of money as a measure of value, a medium of exchange (or means of payment), and a source of "artificial" wealth (Politics 1.9-11). Artificial-as opposed to "natural"-because you can't eat it, or wear it, or live in it; since money has no use-value of its own, acquiring it is not the chief end of the householder, which is to secure a sufficiency of "natural" wealth. The folly of desiring what cannot be itself consumed is evoked by allusion to the fable of king Midas. Aristotle has little patience for commercial traders whose end is amassing money, the reproduction of which by charing interest is the most "unnatural," therefore immoral, activity of all. These views and attitudes, formed in the largely self-sufficient economies of classical Greece, were endlessly repeated in the burgeoning commercial economies of late medieval and early modern Europe, to which they were increasingly irrelevant. Aristotle also noted, in passing, the other "artificial" feature of money: that it is merely "conventional . . . because, if the users substitute another commodity for it, it is worthless." Here, the arbitrariness of the material of money as well as its dependence on social assent are observed, but only further to condemn it as "unnatural."

All these points are repeated by Nicholas Oresme about 1355 in the course of an argument that will be continuously made up to the end of the seventeenth century. The argument is against any debasement or devaluation of the coinage, and it gets made so often because so many princes persisted in doing this, usually to finance their wars. According to Oresme, money is but an instrument for the exchange of "natural riches," an artificial creation the use of which is a public good and public trust. It consists of material precious by its scarcity, which may be diluted by alloy to produce coins of sufficiently small value for everyday transactions (Oresme 1956: 5-7). Since money belongs to and serves the community, it's not for princes to profit from; their stamp merely guarantees its value (11). Any change in its weight or material or form that results in loss of value is fraud, just as it is in any public standard of measure or weight. Altering the coinage is therefore the worst of the 
three illegitimate ways to profit from money (by making it self-begetting), the other two being "banking or exchange" and usury (27).[ $\underline{5}$ ] Princes who devalue the coinage cheat everyone, whereas usurers can cheat only those who willingly borrow, and bankers or moneychangers are merely necessary evils, like brothels.

Minus this latter sort of finely calibrated moral calculus typical of scholasticism, the Aristotelian assumptions of Oresme furnish the same kind of argument for two great thinkers in the sixteenth century, Copernicus and Jean Bodin (Le Branchu 1934: vol. 1). In a memo to the Duke of Prussia written in 1538 to advise him not to debase his currency, Copernicus takes money to be a measure of value whose worth depends on its content of precious metal. He sees that its worth so defined may differ from its face, or nominal, value. If the silver in a coin may be, when melted and extracted, sold for more than the face value of the coin, then this coinage will disappear from circulation, to be thus melted down or hoarded.

Copernicus thus describes the situation later formulated as Gresham's Law-that bad money drives out good-and attributes supreme importance to the control of the precious metal content of the coin. Its value is "just" when that content is only slightly less than its denomination can purchase; and the prince's duty is to maintain that just value.

In a treatise published in 1568, Jean Bodin made the fullest and most cogent contemporary diagnosis of what economic historians call the "price revolution" of the sixteenth century. In the course of it, he reviews much ancient and modern history to show that currency debasement is always an evil for everyone, and to argue that a twelve-to-one ratio of silver to gold was, is, and ever will be their just value. He fulminates against princes who debase their currencies at will, and, like Copernicus, is obsessed with maintaining the "proper" weight and alloy of coins. The obsession is shared by an English writer (known only as W. S.), who published in 1581 a diagnosis similar to Bodin's, in which he attributes all the economic ills of England to Henry VIII's devaluation of the currency (Lamond 1929: 103-04).[ $\underline{6}$ ]

Both Bodin and W. S., however, raise in their diagnosis of the inflation galloping over Europe a problem of valuation which implicitly contradicts their received assumptions about the nature of money. For both perceive that the inflation was launched in large part by the abundant influx of gold and especially silver from the 
new world. The precious content of coins, supposed to fix their value, was itself becoming less scarce, hence less precious. So, as Bodin and W. S. observe at length, money can buy less and less; prices of common commodities have tripled and quadrupled in a generation or two. Money, the supposed measure or standard of value, had become unfixed-not only by the decrees of princes, but because what was supposed to fix it had itself become unfixed. Bodin and W. S. have no way to conceptualize this situation except to insist that values be refixed. For values, to them, are substantial, real, intrinsic, parts of a normative ontological order; if they shift, something is terribly wrong and must be arrested. Hence their fixation on stabilizing the contents of coins, in defiance of their observations that this stabilization is unstable, that gold and silver themselves have no stable value, but fluctuate according to their availability in the market.

And here we arrive at the center of the problem, the formation of the central motive force of the modern world, the placeless market (see Agnew 1986), [ 7 ] the nowhere and everywhere which makes all values mutually relative. No theorist in the sixteenth century managed to conceptualize this, not even those who operated in the market and understood how to manipulate it. What such practitioners did understand, though, was that its operation depended more on credit than on cash.

Now, the devising of credit institutions and instrumentsbanks of deposit, payment orders (the ancestors of cheques), letters obligatory (promissory notes or acknowledgements of debt), and most importantly, bills of exchange-had made possible what one historian calls the "commercial revolution" of the thirteenth century (Spufford 1988: 240-63).[ 8 ] Bills (or letters) of exchange were contractual agreements among a minimum of four people in two different countries recording a payment in one currency in one place, and requiring its repayment in the other place and currency some time later (see de Roover 1953). They were initially devised (in twelfth-century Genoa) as ways to transfer currency and enable international trading of commodities without having to haul bags of silver around. Such paper transfers alone did more to expand trade than any individual currency (Spufford 1988: 262) and made bills of exchange the functional equivalent of money itself (de Roover 1953: 117). But by the late Middle Ages they were being used for more purposes than simply to secure foreign exchange to pay for goods; they had become (disguised) ways of obtaining loans, as 
well as ways of speculating in the fluctuating rates of exchange between foreign currencies (Spufford 1988: 395-96). Finally, they became, by the much-contested practice of endorsement, fully negotiable commercial paper. In an often-cited English lawsuit of 1437, the bearer (not one of its four principals) of a bill of exchange successfully sued for its repayment (Holden 1955: 23-24).[ $\underline{9}$ ] Such negotiability was only sporadically honored by medieval lawcourts, but was widely practiced. Bearer clauses in such contracts were no guarantee, but "the absence of such a clause in an informal bond did not prevent it from passing from hand to hand" (20). Another historian calculates that he volume of credit in circulation during the sixteenth century must have expanded enormously in order to account for the economic growth observable during the period (Dawn 1979: 286).

None of these long-established practices, by which fiduciary paper functions and circulates as money, nor even the very idea of credit, is ever mentioned in the reflections about money of Copernicus, Bodin, or W. S. For they cannot conceive of money as a pure instrumentality, whose value is determined by what it can perform, and not by what it is or contains as an object. They see only that it now performs less, and seek to restore its power by adjusting its content. Another class of writers-merchants who operate in the marketare far more aware that credit is a form of money, and that the power of money is in part measured by how much other money it can buy. But even they are dismayed that the anciently defined measure of value has become a fluctuating commodity in its own market, and so seek to control this market precisely by pegging the currency to a fixed amount of gold or silver.

One of the most famous and skillful of these merchants, Sir Thomas Gresham, advocates the latter and practices the former: that is, he wants the pound to have a fixed, intrinsic value; but he also knows how to manipulate its market value. His operational knowledge that the value of money varies according to its relations of exchange does not remotely disturb his conceptual knowledge that the value of money consists in the amount of precious metal it contains. So in a memo to Queen Elizabeth in 1558, Gresham boasts of having made the pound rise from 15 to 23 Flemish shillings during the reign of Edward VI. (He did it by having the government buy up bills of exchange between London and Flanders.) He advises Elizabeth to take similar steps to keep the pound at its present rate of 22 shillings. This will insure prosperity, he says, since the intrinsic value of the pound 
is but 10 shillings; the high pound will prevent merchants from exporting the country's bullion (Le Branchu 1934: 2.10). How neatly here the concept (of "intrinsic" value) aids the operation: he's doing what governments have done ever since, intervening in a credit market to force up a currency whose "value" can therefore only be measured as its rate of exchange. In another memo of 1559 (plausibly attributed to Gresham), his aim is to control this rate of exchange, to fix it as the amount of any foreign coin that is above and never below the "mint par," the actual precious-metal content (8 carats of gold or 4 ounces of silver) of the pound (de Roover 1949: 291). Here is a real attempt to make the concept and the operation coalesce, to fix the exchangevalue as equal (or more so) to the intrinsic. But that the operation is required, that is, that government must be vigilant to manipulate the exchange, presumes that the concept of the intrinsic is impotent to impose itself. The memo goes on to describe the uses of bills of exchange as instruments of credit and currency speculation-and to deplore these practices. Bankers can place "their money with gayne in any place of the worlde where exchange lieth," and thus "growe riche without travayle and venter" (300). Hence, the bankers must be fought by playing their game and manipulating the market oneself.

A report made in 1564 by a Royal Commission to the Privy Council expresses even more horror at the ability of bankers, "or money merchantes," who deal in no tangible goods, to "use the Exchange onely for gayne by marchandisynge of money, who lye watching to take advantage of the tyme and occasyone to falle or Raiese the Exchange to their moste proffyte" (Tawney and Power 1924: 3.356).[ 10 ] These fluctuations are to be halted by taking measures to fix the exchange rate as near to mint par as possible. This proved virtually impossible in the long term, and subsequent Commissions (in 1576, 1586, 1600, and 1621) took, and had often to rescind, more draconian measures, ranging from licensing only a few persons to draw bills of exchange to prohibiting their use entirely (de Roover 1949: 184). It should be observed that this hostility to the money market is financial, and distinct from the ethical objection to usury as "unnatural" (for that, see Wilson 1572). What is deplored here is the drain of England's bullion when the pound is low, the depletion of that supposedly intrinsic guarantor of money's value. There is also a xenophobic conspiracy theory at work, for the bankers financing much of England's trade at this period are "Lombards" (i.e., any northern Italian) in London and in Antwerp. But the basic hostility is simply to the fact that money can be "merchandised"; that there 
is a money market at all is offensive. And what it offends is the very concept of money as a fixed measure of value.

The same offense, generated by the same contradiction between regarding money as a fixed standard and dealing in it as a commodity, leaves traces even in the more sophisticated continental writers on the subject. As compared to the insular English, the Spanish and Italians generally have a much better, and more tolerant, understanding of the need and importance of credit-for both commerce and governments. A very thorough such understanding is shown even in the scholastic context of making ever more finely calibrated moral/theological judgments on the affairs of merchants, tradesmen, and bankers. This was the task of the Mexican Dominican, Thomas de Mercado (d. 1575), who analyzed at length the legitimacy of all the actual mercantile and financial practices of the mid-sixteenth century. He wrote his treatise in the vernacular (it was soon translated into Italian), expressing some contempt for the ignorance of business that characterized his Latin predecessors, and with the declared aim of being a manual for confessors that will allow them to assess the precise degree of sinfulness in their parishioners' daily affairs (Mercado 1591: 269-70). His distinctions are a good deal more subtle than Oresme's earlier relegation of bankers and moneychangers to the category of prostitutes. For Mercado, exchange between currencies is (unlike usury) necessary and in itself sinless (256). Whether performed in person or by letter, it is a service that justifies payment. What is more, the fluctuating values of currencies make dealing in exchanges a risk which deserves compensation (285-305). So Mercado is not at all horrified by the money market. "Exchange," he blandly explains, used to mean barter, but nowadays in the practice of all nations it means "to exchange one currency for another, bargaining and earning without other merchandise, but only with cash" (246). So merchants and bankers trading their paper debts and exchanges at fairs incur both gains and losses "according to how the market goes" (275). And the market, Mercado emphasizes, has global reach; it carries on trade from Calicut to Mexico via the European centers of Seville, Flanders, and Italy (272-73).

Yet despite his cogent grasp of how the market operates, Mercado makes the usual ethical objections to credit itself, and also retains the old absolute notion of "just" prices and earnings. Thus, any "dry" or "feigned" exchange (whose amount is fictitious), or any exchange in the same place, or any in which the final drawer is one's own factor-all the ways in which bills of exchange 
functioned as loans bearing interest-are simply illegitimate (306, 329, 353). Mercado comes very close to understanding the need for credit; but he cannot, by the ancient definition of usury (money begetting money without risk; money buying time), allow it to be paid for. And he also expresses traditional horror at the cost of commerce-facilitating services generally. He is appalled at high shipping-insurance rates, and thinks that the dealer in money should perforce earn a lot less than the dealer in goods (365-67).

The most sophisticated writer (that I have found) on money and credit in the sixteenth century is Bernardo Davanzati (1529-1606), a merchant-banker, translator, and man of letters who delivered orations to the Florentine Academy on these subjects in 1558 and 1581. In the former of these, Davanzati modifies the Aristotelian definition of money as gold and silver "made by people the price and measure of all things because men came together in such agreement, and not because these metals were worth so much by nature" (Davanzati 1852: 445). After stressing the agency of social assent in creating a standard of value, he illustrates at some length the point that the source and arbiter of all value is not any substance in itself, but rather human needs and desires. Consequently, all values are contingent and variable, "for drinking is more enjoyable when the thirst is great, the desire coming from appetite and taste; the needs of nature, the season, condition, place, quality, rarity and abundance establish the measure in perpetual variation." Thus the worth of the goods of this world, as measured by their prices in gold, is never stable, and can never be determined by some absolute standard, but rather by the operation of what today would be called supply and demand-i.e., the market, in which merchants are the experts. As Davanzati puts it: things are valued "according to whether they are more or less in demand at each place and time. Of such demand merchants are ... well aware, because they are experts in the prices of things" (446). He notes in passing that the influx of gold from South America has tripled prices in Europe since 1534 (447-48), and goes on to stress the necessity for money to circulate, comparing it to the life-blood of the republic (449).

On the basis of this comparison, Davanzati concludes his treatise with a whole series of the usual arguments against debasement and devaluation of the currencyurging especially that the mint not be allowed to make a profit: its job is rather to assure the necessary circulation (455). These arguments, however, unlike the bullionist fixations earlier cited, do not rest on or evoke 
any sense of offended absolute value. They are purely pragmatic, and follow from the need simply to assure the requisite circulation.

And it is the same pragmatic lucidity that has made Davanzati's analysis of credit in his second oration, called "Notizia de' cambi," so useful to economic historians. The interest of his analysis here is its frank acceptance and description of how the market operates to establish values always relative to social needs and desires. And money is just one such ever-fluctuating value: "Marketable things are either goods or money; these can be exchanged, one for another, in three ways: goods for goods, goods for money, and money for money. Hence all mercantile traffic is of three kinds: barter, sale, and exchange." Barter, the simple exchange of goods, was taught to men by nature, who then devised money to facilitate it by buying and selling, and who then devised currency exchanges to facilitate purchase and sale (426-28).These exchanges, invented merely as a way to transfer funds between locations and currencies, gradually became themselves a profit-making market, as merchants began to use the bill of exchange as a credit instrument, a way of obtaining loans:

They then began to open their eyes and to see that with time elapsing between one payment and the other, they could by this means employ the money of the other, and it seemed honest to pay him interest for it . . . so they began to make the second payment a little larger than the first, that is, to give back a little more than they received. Greed for this profit has converted currency exchange into an art; and they give money to be changed not for any need to have it elsewhere, but to have it back with interest; and they receive money to be changed not to draw on it in another place, but to use the money of someone else for a while with interest.(428-29)

Davanzati claims theological approval for these transactions on the basis of their utility alone. If the "art of exchange"-i.e., the granting of credit in the making of loans-did not exist, both the material needs and social pleasures that make human life splendid and blessed would go unsatisfied. Davanzati even allows that such transactions may be motivated by the greed of individuals, and justifies their aggregate result in what seems to be the first statement of classical economic liberalism as it would be preached by Adam Smith: "so that if indeed the intention of individual exchangers is 
not a good thing, the general effect that follows is itself good; and even nature permits many small evils for the sake of one great good, like the death of base animals for the life of the nobler" (429).

Thus justified by nature herself, the market as placeless profit-making holds no horror for Davanzati, who recounts explicitly its evolution from particular placesthe European fairs-to wherever merchants and bankers exchange paper, which he wittily claims "should be called Utopia, that is, a fair without a place." As there need be no place, there need also be no goods. Davanzati gives the example of Lyon as an exclusively financial market, "because people do not go there to buy merchandise, but only fifty or sixty exchangers, with paper notebooks, to settle the accounts of exchanges made in almost all of Europe" (432). But for all his lucidity, even Davanzati shows some discomfort at the ungoverned operations of currency speculators. Still, he justifies the multiplication of florins in Florence by means of a bill of exchange on Lyon with a quotation from Dante, and concludes the treatise with an extended example of how such speculators can make profits by the keen observation of differential rates (435-36).

The reason why they can do so Davanzati understands better than anyone: it is precisely that the rates do differ, that all values are established in the market-determined flux, including those of money, whose "rates of exchange," he insists, "cannot be fixed at par, but go up or down, following the scarcity or abundance of supply, and according to the asking price that the exchange should bear" (436). There is a money market, just like all the others, and Davanzati describes it with none of the outraged disapproval-moral, nationalist, or bullionistexpressed by other writers. What is more, he sees clearly that large-scale commerce depends on credit, that coins need never change hands, that the paper leaves of the cambiatoris' notebooks themselves function as money. And it's the function that matters, not the object.

Davanzati thus articulates the logic of all the subsequent economic developments that continued to be traumatic for those who persisted in regarding monetary values as substantially intrinsic: from the anxiety everywhere aroused by introducing paper banknotes through the currency float of 1971 to yesterday's proposal to return to the convertible gold standard.

The modern economy was operational long before it became conceptual-that is, before the principle of its operation was recognized and formulated. Summarizing the analyses of Davanzati and Simmel, I call this 
principle-the conferring of value by social use in a process of exchange-the fiduciary principle. - From fides, or faith, the term well evokes all the paper exchanges in which we must believe, and which therefore public laws must somehow enforce, in order that the modern economy may function. It is this principle that underlies the necessary and essential role of credit in the economy-another word whose origin (credo) implies the social nexus of shared belief as the sine qua non of monetary and commercial activity. And other terms imply the same: the "trusts" that are both legal arrangements and the institutions that make them; the "confidence" that investors have or lack in a company, commodity, currency, or market. Along with the fiduciary principlethat value results from socially agreed-upon use-goes what I shall call the volitional corollary-that what is thus valuable because exchangeable is also, naturally enough, desirable. As Simmel put it, the price (or value) of an object is high when the sacrifices made to obtain it are great, a situation that can occur only when the object of my demand "is, at the same time, the object of someone else's demand" (1978: 77-78). The modern economic system functions because we believe what others believe and want what others want; values are consequently constituted by the ever-fluctuating relations and conflicts among our mutual beliefs and desires.

While the principle and the corollary were being formulated by Davanzati, the operation of both was being dramatized by Shakespeare. It seems no accident that both men should understand the economy better than most contemporary professional scholars who analyzed it, like Copernicus and Bodin, since both were operators in it: Davanzati as a banker in Lyon during his youth, and the playwright as someone who earned his living as a stockholder in both his acting company and its theatre. The fiduciary principle is dramatized as the political necessity of enforcing an acknowledgement of debt in The Merchant of Venice; and the volitional corollary is explicitly debated as a justification for continuing to fight the Trojan war in Troilus and Cressida. What both the banker and the shareholding poet understood was the crucial importance of "credit"in all its senses.

In the commercial sense, if paper agreements move goods around more efficiently than bagsful of coins, then it becomes a primary function of the state to see that such agreements are honored. The new economic order is based on the validity, the trustworthiness, of the written contract. This situation provides Shakespeare with the main plot of The Merchant of Venice. The broke 
young aristocrat Bassanio, you will recall, needs 3,000 ducats to make a flashy courtship of the rich young heiress, Portia. He seeks the money from his best friend, the merchant Antonio, who acquires it for him only by borrowing it from the Jew Shylock. Antonio signs a bond, which is duly notarized, that failure to repay on the date due will result in his forfeiting a pound of flesh. The forfeit is agreed to as a kind of bitter joke, in lieu of the interest that Shylock usually charges. The lady is wooed and won; but Antonio's ventures miscarry; he can't pay back the loan at the stipulated time, so Shylock has him arrested and brought to a trial which occupies the fourth act of the play.

In the course of this action, the issue at stake is made explicit no fewer than six times. First, when Antonio is arrested, a friend of his tries to console him: "I am sure the Duke / Will never grant this forfeiture to hold." But Antonio, the merchant, knows better. "The Duke cannot deny the course of law," he explains,

For the commodity that strangers have With us in Venice, if it be denied, Will much impeach the justice of the state, Since that the trade and profit of the city Consisteth of all nations. (3.3.24) Second, Shylock petitions the Duke at the trial

To have the due and forfeit of my bond. If you deny it, let the danger light Upon your charter and your city's freedom. (4.1.57)

Third, Shylock rejects all pleas that he relent, and repeats the point: "If you deny me, fie upon your law! / There is no force in the decrees of Venice" (4.1.101). Fourth, Portia, come to court in disguise as an erudite young judge, admits to Shylock:

Of a strange nature is the suit you follow;

Yet in such rule that the Venetian law Cannot impugn you as you do proceed. (4.1.172)

Fifth, Portia concludes her famous speech begging Shylock to show mercy with the same admission:

I have spoke thus much

To mitigate the justice of thy plea, Which if thou follow, this strict court of Venice Must needs give sentence 'gainst the merchant there. (4.1.197) 
Sixth, Bassanio beseeches the supposed judge to "Wrest once the law to your authority; / To do a great right do a little wrong." But Portia replies exactly as Antonio had first replied to the same suggestion:

It must not be; there is no power in Venice Can alter a decree established;

'Twill be recorded for a precedent,

And many an error, by the same example,

Will rush into the state; it cannot be. (4.1.210)

Shakespeare has clearly taken some pains to make the issue perfectly clear: if written contracts are not honored, there is no credibility in Venice, which exists by trade among all nations, and must therefore uphold agreements with no respect to person, nationality, race, or creed. If contracts are not enforced, there can be no economy. The law of contracts is absolute; no individual will, learned or monarchical, can alter it. Mercy is supremely irrelevant here. And it is law, not mercy, that of course solves the problem. Portia discovers in the bond no mention of blood, and so awards Shylock his pound of flesh on condition that he shed no drop of blood. This being impossible, Shylock offers to settle for the money; but Portia rubs his nose in the "justice" he has demanded, insisting he have his forfeit or nothing, and finally convicting him thereby of the attempted murder of a Venetian citizen. The legal system triumphs as it must in a state that lives by commerce. It is this political consequence of the fiduciary principle of the modern economy that Shakespeare has dramatized-a rule of law that upholds contractual agreements among any and all persons: in short, the modern state as opposed to both the feudal oligarchy and the Renaissance monarchy, in both of which laws vary in application according to rank, and can be abrogated by the will of the ruler. It is the kind of state that the first world now has, made necessary by our need to believe in the pieces of paper that we agree to value.

In The Merchant of Venice, the issues of value, credit, and belief are not confined to the main plot-the contracting of the bond and its climactic trial-but also link that plot to the erotic and marital one. Here, the aristocrats must learn that a new form of marriage accompanies the new economic order, that wives too are to be valued differently. But this matter is treated, in this play, primarily in terms of social class. A more general, even philosophical, analysis of the volitional corollarythat value established through exchange is ultimately constituted by desire-is presented in the Trojan council 
scene of Troilus and Cressida. This rather strange, and infrequently performed, play is a corrosive satire on both its titular story of idealized "courtly" love, inherited from Chaucer, and its whole context, inherited from Homer, of the most heroic legend in the West: that of the fall of Troy. Shakespeare simply trashes the traditionally supreme values of love and war, reducing the culture's grandest epic to an affair, as Thersites puts it, between a "whore and a cuckold" (2.3.68). The whore is Helen, stolen by Paris from Menelaus, the cause of the war. In the second scene of the second act, Priam, the king of Troy, holds a council with his sons to consider the latest offer of the Greeks to end the siege and the war if Helen is returned. Hector proposes letting her go because she costs too many lives:

If we have lost so many tenths of ours To guard a thing not ours nor worth to us, Had it our name, the value of one ten, What merit's in that reason which denies The yielding of her up? (2.2.21)

Hector is claiming that the Trojans would not have sacrificed a tenth of the lives already lost for Helen even in defense of one of their own citizens-which Helen is not.

Troilus responds with passionate indignation, saying that the calculation of reasons is irrelevant to the "infinite" honor of their royal house, which is at stake. Hector insists, "Brother, she is not worth what she doth cost / The keeping." Troilus asks, "What's aught but as 'tis valued?" And Hector replies,

But value dwells not in particular will, It holds his estimate and dignity

As well wherein 'tis precious of itself As in the prizer. 'Tis mad idolatry

To make the service greater than the god. (2.2.51)

Hector thus articulates the ancient conviction that worth must be intrinsic to the object, and goes on to attack the younger hotheads who prize things only according to their own individual passions. Troilus then reminds Hector at length that the value of Helen was something they all agreed on: when Paris went to ravish her,

Your breath with full consent bellied his sails ...

Is she worth keeping? Why, she is a pearl Whose price hath launched above a thousand ships 
And turned crowned kings to merchants. If you'll avouch 'twas wisdom Paris went-

As you must needs, for you all cried, "Go, go"If you'll confess he brought home worthy prizeAs you must needs, for you all clapped your hands, And cried, "Inestimable!"-why do you now The issue of your proper wisdoms rate, And do a deed that never Fortune did, Beggar the estimation which you prized Richer than sea and land? O theft most base, That we have stol'n what we do fear to keep! (2.2.74)

After other issues are raised and disposed of (among them the morality of wife-stealing), Troilus will win this argument about value. Hector agrees to keep fighting for Helen, "For 'tis a cause that hath no mean dependence / Upon our joint and several dignities." And Troilus celebrates the decision as the achievement of the traditional aim of all heroic endeavor, "glory." But Troilus describes glory in terms, both religious and economic, that make clear the volitional corollary of the fiduciary principle: value is what others accept, think, and desire. It resides neither in individual desire, as Hector rightly said, nor in the qualities of any object, as Troilus rightly denied. Helen (whom the play depicts as lewd, silly, and superficial) is a pretext, an occasion; she is, says Troilus,

a theme of honor and renown,

A spur to valiant and magnanimous deeds, Whose present courage may beat down our foes

And fame in time to come canonize us;

For I presume brave Hector would not lose

So rich advantage of a promised glory

As smiles upon the forehead of this action

For the wide world's revenue. (2.2.192)

Fame, or glory, is what everyone else will think of us; and it is worth more than the GNP of the entire planet.

The satirical events of the rest of the play (which concludes with Achilles' gang murder of the unarmed Hector) make a concerted effort to destroy the glory of this action, to change our opinion of it, to make it worthless. For Shakespeare's understanding of the modern world and the economic basis of the modern state is ruthless, and requires the rewriting of more than one of Western culture's cherished myths. Those of heroism in particular, along with those of kingship and of 
love, receive radical revision in many of his tragedies, histories, and comedies. But I wish to stress here simply the extent to which Shakespeare grasped the central principle of the new economic order that had been developing for three centuries. It is the fiduciary and volitional basis of a market economy ruled by the social, mutual, general desires of supply and demand, the world where nothing is anything "but as 'tis valued." Paper money, bills of exchange, bonds of debt, Helen of Troy, are what we credit them to be; nothing in themselves, and everything in terms of what we may use and exchange them for. Political and legal and literary systems exist to maintain that credit and make possible those exchanges. The genius of Shakespeare has been often praised as universal-"not of an age, but for all time," as Ben Jonson put it. But even after four hundred years, it's a little too early to tell. For his age is still ours. Since his own lifetime, Shakespeare has passed for universal easily enough because he described so accurately the world in which we still live.

That we still live in it is illustrated by Lyotard's claim for the effect of computerized language: to transform it into a "productive commodity." I have sought to show that this process entered the consciousness of modernity in the sixteenth century, when the commerce that requires credit-long recognized only to be deplored--and the determination of all values as contingent on exchange were beginning to be both conceptualized and enacted on the stage. Shakespeare's theatre was itself the Occident's first professional, corporately organized, industry of mass entertainment-precisely a way of marketing language as a commodity. The units of language it marketed remain, fortunately, more interesting than most of the infobytes exchanged today on our machines (and, of course, remain themselves available for dissemination on those machines). The computer aids the economy to accomplish its indeed infinite aim: the "extension of markets."

Today, this aim is busy with the formerly non-capitalist economies of the (no longer) second world. In Shakespeare's time, it was busy with the lately discovered new hemispheres, and the populations that now (insofar as they have survived) sometimes call themselves the "fourth world" (i.e., indigenous peoples marginalized by the economy in whatever nation). It was this initial "extension of markets" that supplied the motive for both European colonialism and the analysis of its effects at home. The reason that sixteenth-century writers were trying to conceptualize the economy, the 
condition that required analysis, the problem as it was perceived, was the new wealth and the unprecedented inflation that resulted in the old world from its exploitation of the new. Shakespeare's Antonio, we recall, has "ventures" to Mexico and the Indies (1.3.18). And as the material economy was acquiring colonies as a source of profit, the literary economy was making these "adventures" heroic (cf. Nerlich 1978), rewriting the risk of life as the risk of capital. Bassanio is Jason, whose trip requires financing; his visit to suburban Belmont to court his "golden fleece" (1.1.170) is the equivalent of Jason's sailing to the end of the known world to find his.

Shakespeare trashes the old, aristocratic legends only to appropriate their symbolic capital for the bourgeoisie. His success at this, and his subsequent enthronement as the monarch of the modern literary canon, might suggest new perspectives on familiar developments in literary history: the replacement of the epic by the novel, the novel's bifurcation into lighter picaresque and heavier domestic psychology, the perennial survival of "romance"-so popular as to cease being qualified as literature, and the development of professional criticism and teaching of vernacular literatures as one of the institutions that does the qualifying and the canonizing. All these are parts of a value-creating system, offering models of, or arguments for, what we should desire; and all function as and in relation to the system that produces and exchanges commodities and services for cash, on credit, around the globe. Words-including that use of them called literature-and money-especially that which generated and was generated by the European colonization of the world-are not just systemically homologous; they are historically, at least from the beginning of the sixteenth century until now, inseparable.

\section{References}

Agnew, Jean-Christophe. 1986. Worlds Apart. New Haven: Yale Univ. Press.

Aristotle. 1947. Introduction. Ed. Richard McKeon. New York: Random House.

Clodd, Edward. 1938. The History of the Alphabet. New York: Appleton-Century. 
Davanzati, Bernardo. 1852. Opere. Ed. Enrico Bindi. Florence: F. Le Monnier.

The Dawn of Modern Banking. 1979. Papers from the Center for Medieval and Renaissance Studies, UCLA. New Haven: Yale Univ. Press.

de Roover, Raymond. 1949. Gresham on Foreign Exchange. Cambridge: Harvard Univ. Press.

de Roover, Raymond. 1953. L'Evolution de la Lettre de Change XIVe-XVIIIe siècles. Paris: Armand Colin.

Foucault, Michel. 1970. The Order of Things. New York: Pantheon.

Halpern, Richard. 1991. The Poetics of Primitive Accumulation: English Renaissance Culture and the Genealogy of Capital. Ithaca: Cornell Univ. Press.

Holden, J. Milnes. 1955. The History of Negotiable Instruments in English Law. London: Athlone.

Lamond, Elizabeth, ed. 1929. A Discourse of the Common Weal of this Realm of England. Cambridge: Cambridge Univ. Press.

Le Branchu, Jean-Yves, ed. 1934. Ecrits notables sur la monnaie. 2 Vols. Paris: Félix Alcan.

Lehrman, Lewis E. 1990. 'The Curse of the Paper Dollar.' The Wall Street Journal Europe, 8 November.

Lyotard, Jean-François. 1993. Political Writings. Tr. Readings and Geiman. Minneapolis: Univ. of Minnesota Press.

Mercado, Thomas de. 1591. De' Negotii, et contratti de mercanti. Brescia: Marchetti.

Nerlich, Michael. 1987. Ideology of Adventure: Studies in Modern Consciousness, 1100-1 750. Tr. Ruth Cowley. Minneapolis: Univ. of Minnesota Press.

Oresme, Nicholas. 1956. De Moneta. Tr. Charles Johnson. London: T. Nelson.

Polo, Marco. 1938. The Description of the World. Tr. Moule and Pelliot. London: George Routledge.

Readings, Bill. 1991. Introducing Lyotard: Art and Politics. London: Routledge. 
Rossi-Landi, Ferruccio. 1968. Il linguaggio come lavoro e come mercato. Milan: Bompiani.

Rossi-Landi, Ferruccio. 1977. Linguistics and Economics. The Hague: Mouton.

Saussure, Ferdinand de. 1959. Course in General Linguistics. Ed. Bally, Riedlinger, and Sechehaye. Tr.

Wade Baskin. New York: McGraw-Hill.

Shell, Marc. 1978. The Economy of Literature. Baltimore: The Johns Hopkins Univ. Press.

Shell, Marc. 1982. Money, Language, and Thought. Berkeley: Univ. of Calif. Press.

Simmel, Georg. 1978. The Philosophy of Money. Tr. Tom Bottomore and David Frisby [of 2d ed., 1907]. London: Routledge and Kegan Paul.

Smith, Barbara Herrnstein. 1988. Contingencies of Value: Alternative Perspectives for Critical Theory. Cambridge: Harvard Univ. Press.

Sohn-Rethel, Alfred. 1978. Intellectual and Manual Labor: A Critique of Epistemology. Atlantic Highlands, N.J.: Humanities Press.

Spufford, Peter. 1988. Money and its Use in Medieval Europe. Cambridge: Cambridge Univ. Press.

Tawney, R. H. and Eileen Power, eds. 1924. Tudor Economic Documents. 3 vols. London: Longmans Green.

Vilar, Pierre. 1976. A History of Gold and Money 1450-1920. Tr. Judith White. London: New Left Books.

Waswo, Richard. 1987. Language and Meaning in the Renaissance. Princeton: Princeton Univ. Press.

Wilson, Thomas. 1572. A Discourse upon Usury. Ed. R. H. Tawney. New York [1925]: Harcourt Brace. 


\section{NOTES}

1. 'Consuetudo vero certissima loquendi magistra, utendumque plane sermone ut nummo, cui publica forma est' (Institutio Oratoria 1.6.3).

2. Unaided by Simmel, Barbara Herrnstein Smith is at pains to make this a central argument of her excellentContingencies of Value (1988).

3. I have elsewhere (Waswo 1987) described the dilemmas that repeatedly occur in various sorts of Renaissance arguments about language.

4. Lehrman, Lewis E. 1990. "The Curse of the Paper Dollar."The Wall Street Journal Europe, 8 November.

$\underline{\mathbf{5}}$. Oresme, Nicholas. 1956. De Moneta. Tr. Charles Johnson. London.

6. Lamond, Elizabeth, ed. 1929. A Discourse of the Common Weal of this Realm of England. Cambridge.

7. Agnew, Jean-Christophe. 1986. Worlds Apart. New Haven, Conn.

8. Spufford, Peter. 1988. Money and its Use in Medieval Europe. Cambridge.

9. Holden, J. Milnes. 1955. The History of Negotiable Instruments in English Law. London.

10. Tawney, R. H. and Eileen Power, eds. 1924. Tudor Economic Documents. 3 vols. London.

Accueil Surfaces | Table des matières | Recherche Surfaces Home Page | Table of Contents | Search

PUM | Livres | Revues | Publications électroniques | Vente et distribution 